\title{
Burma's struggle for democracy: the army against the people
}

\section{Abstract for chapter 5}

\section{Author: Josef Silverstein}

Since 1948 Burma has struggled, both to establish a modern democratic political system, and to unite the people under its rule. So far, it has failed on both counts.

The author outlines democracy and its roots in Burma before moving on to describe the military's roots and to give an overview of the three phases of military rule: from 1962 to 1974; from 1974 to 1988, and from 1988 to 1993 . Also covered are the opposition to military rule between 1962 and 1988, and the unity of the army from 1948 to 1988.

The author concludes that finally military rule has convinced even the most sceptical that a true democracy is the only way to domestic peace, freedom and personal safety.

\section{Keywords}

Anti Fascist People's Freedom League (AFPFL), Aung San, Buddhism, federal union, People's Volunteer Organisation (PVO), State Law and Order Restoration Council (SLORC) 


\section{5 \\ BURMA'S STRUGGLE FOR DEMOCRACY: \\ THE ARMY AGAINST THE PEOPLE}

\section{Josef Silverstein}

The decade of the 1990s opened with the people cautiously hoping for change in the future of Burma. After twenty-eight years of military rule, in one guise or another, many were optimistic that the 1990 scheduled elections would begin a process by which they would recover power and restore democracy.

Almost from the day they regained their independence from British rule in 1948, their nation has been torn by civil war, which persists to this day, foreign invasion and slow economic recovery from the devastation wrought by World War II. The people were sorely tested in 1988 when they demonstrated for freedom and change but were met with the guns and bullets of the army as it suppressed their peaceful revolution. And even though they complied with martial law, and participated in the election of May 1990 to vote for members of a national assembly as a first step toward the restoration of democracy, their patience went unrewarded as the military found one excuse after another to delay change. All real hopes for peaceful change were dashed in September 1991, when Major-General Tin U said, 'We cannot say how long we will be in charge of the state administration. It might be five or ten years' (South China Morning Mail 11 September 1991).

On 23 April 1992 the State Law and Order Restoration Council (SLORC) began a series of actions which were intended to signal that political change was beginning. Under a new leader, SLORC started to release political prisoners and took the first steps toward writing a new constitution. These and other changes provide a preview of the future political system which the military rulers in Burma are trying to establish, a system where the military will play the leading role and the people will be the approving chorus. The model the soldiers-in-power have in mind derives from the present Indonesian system (The New Light of Myanmar 24, 25 June 1993). This is the political burden the people carry as they continue to struggle to free themselves from tyranny and dictatorship. 


\section{Democracy and its Roots}

Before Burma regained independence on 4 January 1948, an uneven leadership struggle developed between the older leaders of the prewar period and the young men who had formed and led the wartime Burma army and the coalition nationalist party, the Anti Fascist People's Freedom League (AFPFL). While the former were prepared to work within the framework of change offered by the British, the latter were not. The people backed the AFPFL from the outset, and its legal right to lead was confirmed in the 1947 election and in the constituent assembly.

Before the authors of the 1947 constitution took up their task they had, at least, three traditions to draw upon. They could have returned to some form of monarchy, such as existed before British rule (Koenig 1990:65-97). But that idea had been rejected during the war period when the Japanese granted Burma independence (Cady 1958:4-5) and again by Aung San, the nationalist leader, when he addressed the AFPFL on the eve of the constitutent assembly (Silverstein 1972: 92-100). They could have created a bureaucratic-authoritarian system, after the model the British instituted at the end of the nineteenth century or that of the constitutional dictatorship fashioned by Dr Ba Maw, under Japanese tutelage, during World War II (Christian 1945:60-76; Maung 1959: 54-62). This, too, was rejected. They had a third model, parliamentary democracy, which the British introduced as early as 1921 to put the nation on a course to self-rule (Christian 1945:77-105).

Most amongst the young elite were Buddhists and were influenced, to various degrees, by Buddhism's values and traditions. Many, however, like their leader Aung San, were Western-educated, holders of university degrees and believers in liberal democracy with its emphasis upon separation of church and state. They came to maturity in a period when democracy was evolving in Burma and they were able to study and debate the political ideas of their day - democracy, fascism, communism - and the meaning and content of Burmese nationalism. Overwhelmingly, they were drawn to socialism, secularism and democracy (Khin Yi 1988; Silverstein 1980:134-161). These ideas were foremost in the thinking of Aung San when he addressed the preconstituent assembly meeting of the AFPFL and committed the party to their support (Silverstein 1972).

But there were divisions within the AFPFL. In a barely disguised struggle between communists and socialists rival leaders and member parties fought for control of the AFPFL and influence in shaping the future constitution. In 1946 the communists were expelled from the AFPFL and the ideas of the socialists, together with those of Aung San, were influential in the writing of the basic law.

The constitution of 1947 created a parliamentary system with two legislative chambers. It included a renunciation of war as an instrument of policy, a set of socialist- 
influenced unenforceable goals - called directive principles, a definition of relations of the state to peasants and workers, and fundamental human rights for all.

The AFPFL leaders had a special problem in that nearly 40 per cent of the population were members of various minority groups who lived either amongst the Burman (the Karens and Mons) or in the hill areas which surrounded the heartland (the Shans, Kachins, Chins and others). Because the minorities either had been given special treatment under British rule (the Karens formed a separate electorate and were given a specific number of seats in the legislature) or had been excluded from the evolving political process during the same period (the various hill peoples), the question of uniting everyone in the territory of Burma proved vexing. Discussions leading to promises made by the Burman leaders to the minorities resulted in the creation of a unique federal union, which was more unitary than federal, and led to most Karens and Karennis rejecting it. It also promised the right of secession to the populations of two areas but denied it to all others. Failure to solve the problems of national unity at the outset was a major cause of minority revolts after independence (Silverstein 1980).

Internal wars tested the nation. Between 1948 and 1952 the government nearly collapsed as it fought to recover control first of the heartland and then of the hill areas. Yet even as it faced the threat of being overthrown and the union destroyed, the legislature met and acted, a national election was held, the High Court and Supreme Court upheld civil and political rights against the effort of the government to ignore them in its determination to restore control and domestic peace, education expanded at all levels, and the press flourished as one of the freest in all of Asia.

Religion and politics were never far apart. The 1947 constitution established religious freedom, but in the same chapter it declared that Buddhism enjoyed a 'special position'. As early as 1949, a Ministry of Religious Affairs was created and ecclesiastical courts were established. The state also conducted religious examinations and sponsored an international Buddhist celebration to commemorate the Buddha's 2500th birthday (Mendelson 1975:112).

Although the state was declared to be the ultimate owner of all the land, in fact agricultural lands were in private hands and the farmers were free to buy and sell and to make all farming and marketing decisions. While some economic enterprises, such as transportation and power generation, became government monopolies, there was a private economic sector which flourished alongside government businesses and cooperatives.

Despite a non-aligned foreign policy and the illegal invasion and occupation of some of its territory by remnants of the Chinese Nationalist Army - causing the government to divert resources from economic recovery and development to the expansion of the army and the purchase of weapons - the economy slowly recov- 
ered to near prewar levels in all areas; many of the groups in revolt either ended their war and returned home or, if they continued to fight, were driven into the hills and the delta area. In 1956 the nation held a second national election which generally was free and fair and produced an opposition party in parliament which generated lively debates and moved the nation from a one-dominant-party to a multiparty system (Silverstein 1956). The institutions of democracy began to grow in an atmosphere of peace and stability.

But unity and stability in the AFPFL leadership did not last. In 1958 the leaders split and, in their struggle to win control of the party and government, the rivals provoked a constitutional crisis. Prime Minister Nu tried to resolve it through a vote in the parliament; but even though he won, his margin was small and his backing came mainly from the minorities rather than the Burman members. Having no dependable majority in parliament, on 26 October $\mathrm{Nu}$ stepped down as prime minister and recommended General Ne Win, the military commander, to form a caretaker government and restore political conditions under which new elections could be held to resolve the political crisis.

This was not the first time that Ne Win was brought into government. In 1949, at the height of the rebellions, Nu asked him to serve as deputy prime minister and take charge of several ministries following the mass resignation of the socialists from his cabinet. Ne Win held those posts for nearly seventeen months.

The multiple internal wars in the decade of the 1950s gave Ne Win's army the opportunity to exercise political authority under martial law. In 1952 martial law was proclaimed in parts of the Shan state; it lasted for two years. The army abused the people and acted corruptly, giving rise to its reputation of ruthless and autocratic behaviour. Whatever popularity it had in the hill areas at the outset of its rule vanished as it exercised power.

$\mathrm{Ne}$ Win's caretaker government of 1958-60 ruled without party support. It drew upon senior military officers and respected civil servants to serve in the cabinet and administer government offices. Ne Win scrupulously adhered to the letter of the constitution, even demanding its amendment to allow him to serve beyond six months as a nonelected member. But his strict enforcement of the law, insensitivity to the people, and impatience with the democratic process, turned the public against his rule even though his administration brought law and order to a good portion of the country and improved the economy.

Like the government before his, Ne Win's had no compunctions against using religion for political ends. In 1959 it published a booklet entitled Dhammantaraya (Dhamma in Danger), which declared that the Burmese communists posed a threat to Buddhism, and mobilised 80800 monks to hold meetings and denounce the local communist movement (Ba Than 1962:71). It also continued the practice 
of mixing religion and politics by placing religious affairs under the deputy prime minister and enforcing all laws pertaining to religion.

When elections were held in 1960, the party favoured by the military suffered an overwhelming defeat while its opponent, led by $\mathrm{U} \mathrm{Nu}$, returned to power (Director of Information 1960; Silverstein 1977). A major issue was U Nu's promise, if elected, to make Buddhism the state religion.

Between that election and the military coup on 2 March 1962, Nu worked hard to strengthen democracy and address the causes of national disunity (Silverstein 1964). But before he could accomplish his goals the military struck, seized power, and replaced democracy and the constitution with a military dictatorship.

Although the democratic experiment lasted only fourteen years, it established an important watershed for Burmese political thought and action. Three national elections had been held and a multiparty system proved workable; leaders coped with major economic and political problems and adopted pragmatic solutions. Human and civil rights generally were honoured, and when questions arose the courts acted independently in defence of the constitution.

Divisions in the ruling party were a major cause of criticism of the democratic process; however, it must be remembered that the AFPFL started life as a broad coalition of conflicting leaders and ideas. In the face of multiple rebellions which threatened to destroy the union as well as the democratic system, the leaders generally remained united. In 1958, when the nation began to enjoy real peace and thousands of people in revolt began to put away their weapons and drift toward a peaceful way of life, Nu tried to convert the AFPFL into a coherent and unified party; but divisions amongst its leaders already were evident and barely concealed in the party congress of that year. Three months later, AFPFL unity was shattered. A similar phenomenon occurred in U Nu's party during his last administration and reinforced the idea that personal rivalries outweighed commitment to democratic rule. If the people did not rise up to defend democracy against the military in 1962 it was because most of those who thought about it recognised the reality of a totally successful lightning coup and because many of them believed that a new caretaker government was going to be established.

\section{The Military and its Roots}

The modern military in Burma began as part of the independence struggle in the 1930s. In 1940 the Thakins, the political movement of the students and young intelligentsia, secretly sent one of their leaders, Aung San, to China to seek aid for their revolt. Picked up by the Japanese in Amoy, he was taken to Tokyo. There he met leaders of the Japanese Army command who were aware of the independence 
aspirations of the Thakins; Aung San entered into an agreement with them: 'Japan would help Burma to gain her independence by supplying her with necessary arms' (Ba Than 1962:15; Yoon 1973). At the same time, an underground revolutionary movement began to form inside Burma in preparation for the anticipated uprising against the British.

Aung San returned in 1941 and recruited twenty-nine Burmans to go secretly with him to Hainan Island where they would be given military training by the Japanese. These 'Thirty Heroes' formed the nucleus of the present Burma army. When the Pacific War broke out, they returned to Thailand, recruited the first members of the Burma Independence Army and followed the Japanese into Burma. Some of their units fought the British and the experience gave them pride and confidence. During the war the army's name was changed, first to the Burma Defence Army, then the Burma National Army and at war's end, to the Patriotic Burmese Forces. On 27 March 1945 it revolted against the Japanese and joined with the Allies in their final phase of the war against the Japanese in Burma.

There was a second strand to the modern Burma military: the ethnic minorities who were recruited and served in the pre-war Burma Defence Forces. During peacetime the colonial rulers recruited very few Burmans. Only in times of emergency - World War I and at the beginning of World War II - were the armed forces open to Burman recruits.

Following the defeat of British forces in Burma in 1942, minority recruits who did not escape to India returned to their villages in the hill areas and, there, were regrouped by British officers who stayed behind or were dropped by parachute to prepare for the return of the British army (Morrison 1947; Mountbatten 1960).

Shortly after the British were driven out of Burma in 1942, there were serious clashes between the Burma Independence Army and Karens living in the delta region. To overcome racial tensions, Aung San and other Burman leaders convinced some Karen leaders of their determination to build racial harmony by recruiting Karens into the new indigenous army and commissioning a few Karen officers. Following independence, a British-trained Karen officer, Smith Dun, was named the first head of the Burma army.

After the war, the Supreme Allied Commander, Admiral Mountbatten, met with Aung San and other Burman leaders in Kandy, Ceylon, where they agreed that the new Burma army would be created out of the two different military groups. It would contain approximately equal numbers from both and would be organised along racial lines on the model of the Indian Army. At the outset, it would employ British officers while Burmese officers were being trained to British standards. The armed force would be limited to approximately 10000 officers and men.

The two elements brought different values and attitudes to the new army. The 
Burmans drew upon the ideas of the Thakins - opposition to colonial rule, independence and socialism. From their wartime experiences, they adopted the Japanese military ideas of loyalty, instant obedience to commands from above or punishment for their failures. They also learned to respond unquestioningly to authority and not to act independently in battle, no matter what the conditions. Their experiences in battle against the British and the Japanese gave them a sense of self-confidence, a belief in themselves as the leaders who played an important role in bringing the AFPFL into being, and pride in their patriotism for having fought for the political freedom of Burma.

The minorities brought a different tradition: loyalty to the British monarch, military professionalism, separation between politics and military affairs, and fear of Burman domination.

There was also a third element of the military - private armies. Such forces existed in the 1930s and were nothing new for Burma. Aung San formed the Peoples Volunteer Organisation (PVO) from the Burman soldiers who were not taken into the new army, as a home guard to help maintain law and order in the countryside. But its real mission was political: to give the AFPFL a vehicle by which to intimidate the colonial rulers in the growing struggle for independence. Because PVO members shared the ideas and values of and had close personal ties to the leaders and men in the new army and the rival political parties in and out of the AFPFL the socialists and communists - doubts were raised in many minds as to whether there was a real separation between the professional army, the political army and the parties. So long as Aung San lived, the PVO remained united and loyal to him and the AFPFL. Aung San's assassination in 1947 left the PVO leaderless and subject to the persuasions of rival political groups seeking to lead the nation.

The communist uprising in 1948 split the PVO, with members divided between the government and its opposition. The PVO eventually faded as a military and political force, but not before its involvement in the civil war nearly tipped the scale on the side of those in revolt.

During this same period the minorities, too, were torn between loyalty to the new state and loyalty to their ethnic groups. The Karens, in particular, experienced a sense of abandonment by the British to their historic oppressors, the Burmans. This helped raise their ethnic consciousness at the expense of full identity with the new national army. In 1947 the Karens formed a paramilitary group, the Karen National Defence Organisation (KNDO) to defend their villages. At the same time, the other large minorities, the Shans, Kachins and Chins, gave their full loyalty to independent Burma. In the early phases of the rebellions their loyalty to the Union of Burma and their unwillingness to join the Karens and others in revolt was a major factor in saving the union. 
The Kandy Agreement, which emphasised federation rather than full integration, had a second defect. It took no account of the political divisions and competing ideologies amongst the member groups in the AFPFL and their reflection in the new army. Thus, when the Communist Party went into revolt on 28 March 1948, less than three months after independence, the army began to come apart. The $1 \mathrm{st}$ and 3rd Burma Rifles - two Burman battalions - deserted with their weapons and joined forces with the revolutionaries. Two months later the PVO split, one part joining the communists in revolt and the other remaining loyal to the government.

Following independence and the failure of the constituent assembly to solve the problem of the Karens' place in the new union, communal violence erupted between Burmans and Karens. As the violence increased, in January 1949 the KNDO went into revolt. Three battalions of Karen Rifles deserted and joined the KNDO.

These events brought a change in military command; Smith Dun was placed on indefinite leave and $\mathrm{Ne}$ Win was placed in charge of the army. The government authorised the recruitment of PVOs loyal to the state, and other former World War II soldiers to form territorial units (Sitwundans) to buttress the depleted army (Tinker 1961:38). Under Ne Win's leadership, a process of Burman domination in the army began. Despite the loyal support given by Kachin, Chin and Shan battalions, their units gradually were reformed with Burman officers in command and Burman soldiers in their ranks. Aung San's federated army gave way to Ne Win's Burman-dominated and integrated army. The new army became more professional with the establishment of a military academy in 1954, and later a National Defence College. As its size grew, so too did its strength in arms.

In the midst of the political turmoil caused by the 1958 split in the AFPFL, the military feared that the primary loyalty of the Union Military Police (UMP) and paramilitary forces was to political parties rather than the state and that UMP units might take sides and even displace the army as the nation's defender. It also was alarmed at the divisions in the ranks of the nation's leaders. In this deteriorating environment the army saw itself as the only national institution ready to sacrifice itself to preserve the union and protect the constitution.

On the eve of the formation of the caretaker government the military leaders held a conference at which they defined the national ideology, as they understood it, and their role in upholding it (Director of Information 1960: Appendix I), declaring that so long as their strength remained, 'the Constitution shall remain inviolate'. They held that the nation's goal was to build a political-economic system on the principles of justice, liberty and equality. To gain that end, they set three priorities: first, to restore peace and the rule of law; second, to construct a democratic society, and third, to create a socialist economy. They pledged to pursue the aims of national politics as distinct from party politics. When Ne Win presented 
himself to parliament as candidate for the office of prime minister on 3 October 1958, he said:

I wish deeply that all Members of Parliament would hold as much belief in the Constitution and democracy as I do. I wish deeply that all Members of Parliament would sacrifice their lives to defend the constitution as I would do in my capacity of Prime Minister, as a citizen and as a soldier (Director of Information 1960:547).

The caretaker government gave Ne Win a chance to put the army's ideology and theories into practice; and as discussed earlier, while he followed the letter of the constitution, he violated its spirit.

\section{Military Rule: First Phase, 1962-1974}

The military justified the coup of 2 March 1962 on three grounds: to preserve the union, to restore order and harmony in the society, and to solve the economic problems facing the nation (Silverstein:1977:80). The men who made the coup were not the same as those who stood close to Ne Win in the caretaker period. Several had been sent abroad as ambassadors a year earlier. And those who remained were divided in their view of what the military should do with power. Brigadier Aung Gyi wanted to continue along the lines of the caretaker government, while his rival, Brigadier Tin Pe, wanted to turn the nation immediately down the road to socialism. A year later Aung Gyi was dismissed and Ne Win adopted Tin Pe's position.

If the coup leaders were divided on their immediate course, they were agreed on abandoning their earlier commitment to the constitution and democracy in favour of dictatorship with no limits on their right to make rules and exercise power.

A month after the coup the leaders promulgated a new ideological statement, The Burmese Way to Socialism. In their new analysis they argued that Burma's problems were the result of the economic system, which not only deformed society and the personal values and attitudes of the people, but contributed to disunity and social unrest (Silverstein 1964:716). Parliamentary democracy also contributed by failing to produce political stability and lent itself to misuse and personal profit by those in power. Thus, the priorities were altered: economic change and the creation of a socialist democracy - on the lines of the Eastern European states must come before all else. Gone were all pretences of upholding constitutionalism and the liberal democracy of the past.

From the outset, the military displaced the institutions created at independence, replaced the civilian leadership with members of their own organisation, and substituted their thought for that of their political predecessors. The constitution 
was suspended and became inoperative in areas where the Revolutionary Council, the military governing body, issued decrees and promulgated orders. The courts were changed. The old parties were outlawed and replaced by the military's own new party, the Burma Socialist Program Party (BSPP), the only political party allowed after 1964. The free press eventually was outlawed and replaced by an official publication, the Working Peoples Daily. Most of all, the federal system, while remaining in name, in fact became a centralised administrative system. Security Administration Councils, composed of representatives from the army, civil service and police, replaced state political and administrative organs. The new system was organised hierarchically with control located in Rangoon.

The changes were more than institutional. The people were cut off from contact with foreigners as the military's propagandists and educators sought to change people's beliefs, values and attitudes to those expressed in the new ideological documents. A police state emerged; people were required to inform on one another while a national network of domestic spies reported the activities and statements of ordinary citizens.

To bring an end to the various revolutions still in progress, the military rulers used both 'carrot' and 'stick', holding peace negotiations in 1963 and, following their failure, resuming their military campaigns.

The Burmese way to socialism failed both to improve the economy and to gain real support amongst the people. By the end of the decade Ne Win and his coleaders gradually shifted to a new direction.

In 1971 the BSPP was converted from a cadre to a mass party and $\mathrm{Ne}$ Win gave it responsibility for writing a new constitution. Despite changes in structure, the party remained a political vehicle for the military with General Ne Win as its head and senior military officers monopolising all subleadership posts.

In April 1972, while the party pursued its tasks, Ne Win and nineteen senior military officers retired from the Defence Services. At the same time the government changed its name from the Revolutionary Council to the Government of Burma. U Ne Win remained prime minister and most of the same senior military leaders, now retired, continued as government heads; four civilian cabinet officers were added to their ranks. During this period Ne Win abolished the secretariat inherited from the British colonial system, and transferred its responsibilities to the ministers. In terms of who led the nation, these changes were more nominal than real as the military retained its near exclusive control of power. A new constitution was approved by the people in a referendum in December 1973, and in elections held the following month candidates for seats in the national assemby and the three sublevels of government were elected. On 2 March 1974 the second phase of military rule began. 


\section{Military Rule: Second Phase, 1974-1988}

Despite the fanfare, the military did not return power to the people. The constitution institutionalised the power of the BSPP. It was directed to lead the nation; no other parties were allowed. It selected all candidates for seats in the national assembly, the Pyithu Hluttaw, and the deliberative bodies at the three lower levels; and it was empowered to give advice and suggestions to government. If there was any doubt that the new system was a continuation of its predecessor, Article 200 declared that when the People's Assembly interpreted the constitution, it had to do so in accordance with the General Clauses Law promulgated by the preceding government.

Like the army, government was centralised and hierarchical. The various levels of administration were tied together by the principle of democratic centralism. The people were given rights and duties. They had the right to stand for election and to recall their representative; they had the right to freedom of thought, conscience and religion; the right to freedom of speech, expression and publication 'to the extent that the enjoyment of such freedom is not contrary to the interests of the working people and of socialism' (author's emphasis). In carrying out one's rights, the constitution declared that persons 'shall be under a duty ... to abstain from undermining any of the following: (1) sovereignty and security of the State; (2) the essence of the socialist system; (3) unity and solidarity of the national races; (4) public peace and tranquility; (5) public morality'.

With no right to organise a political party to express legal opposition to the ruling party and the government it controlled, with the requirement to report the speech of others as well as one's own conversations with outsiders, with police informers everywhere, the rights were nominal, at best, and meaningless in this constitutional dictatorship.

The system remained intact, with relatively little change until 1988. At the Fourth Party Congress (August 1981) Ne Win announced his intention to give up the office of president of the nation, but to continue to serve as head of the party. As this was where real power was located, it did not represent any real change. His potential successor, U San Yu, was a former subordinate officer from the time he served under $\mathrm{Ne}$ Win in the 4th Burma Rifles. Other nominal changes were made but, as always, power remained in the hands of serving or retired military officers under Ne Win's leadership (Silverstein 1982).

The first sign of real change came in August 1987, when Ne Win startled the nation by admitting 'failure and faults' in the management of the economy and called for open discussion about the past and change. Within weeks the heavy hand of socialist economic control was partially lifted as the government removed restrictions on the sale, purchase, transport, and storage of foodstuffs. This was followed by demonitisation of three units of currency, which was intended to disrupt the black 
market but in fact had a devastating effect upon the general population because most did their business in cash and kept their reserves at home instead of in a bank.

Developments came to a climax in July 1988 while the nation was in turmoil and an emergency party congress was in session. Ne Win announced his resignation as party head and urged the leaders to consider the creation of a multiparty system, among other changes. He also warned the nation not to demonstrate, for if they did, the army would not shoot over their heads.

Although the party permitted Ne Win to resign, it did not adopt his recommendations. Instead, it appointed as its new leader General Sein Lwin, another protégé of Ne Win. He had the reputation of having led his military unit in suppressing dissent on the university campus in 1962, and again in 1974 where hundreds of students were killed or wounded. To put down the growing national unrest, which had been building up during the year and was about to culminate in a national strike on 8 August, Sein Lwin ordered the military to suppress the strike of unarmed civilians; it resulted in the death of thousands.

The resignation of Sein Lwin brought the first true civilian to leadership. Dr Maung Maung, a legal scholar and strong supporter of Ne Win, became head of state and sought to end popular unrest by promising elections for a multi-party system and other reforms. But his offer came too late as dissent grew and threatened to topple his government; more important, defections from the air force and the navy to the side of the people were a prelude to defections from the army. During this period, the government released criminals from jail and crime rose; at the same time, it spread rumors that the water was poisoned and the city was unsafe. Instead of drawing the people back to BSPP rule, this only hardened their resolve to continue peaceful demonstrations for immediate change to a democratic multiparty system.

At this critical stage, when the people felt that they were on the verge of victory, General Saw Maung, the head of the army, organised a coup and on 18 September seized power and ordered the armed forces to suppress all dissent. Again, the number killed and wounded is unknown, but is reported to have reached 3000 or more.

Thus, within a year, from Ne Win's 1987 announcement to the Saw Maung coup, the military's carefully constructed constitutional dictatorship crumbled and the army found it necessary to abandon the façade of constitutional government in favour of naked power to restore its leadership. As in 1962, it abandoned all pretences of legality and democracy to create a new dictatorship based on martial law and backed by soldiers and guns.

\section{Opposition to Military Rule: 1962-1988}

Despite having complete political power and the backing of the armed forces, 
military rule in its various guises was never free of opposition. The civil war between the minorities and the government persisted even though the armed forces increased in both size and strength. In the heartland, Buddhist monks and university students resisted openly at various times. As the military was fashioning its dictatorship in 1962, the monks refused to register and carry identification cards; and in the Mandalay area some monasteries resisted with force. Eventually, in 1980 $\mathrm{Ne}$ Win was successful in bringing the monks and the various sects under government control and marked the event by holding a national celebration, granting amnesty to dissidents and imprisoned felons.

The opposition of the university students lasted longer and was more influential in bringing the constitutional dictatorship to an end. It began in June 1962, with resistance to harsh new university regulations and the killing of an unknown number of students as the army dislodged them from their barricades on the campus and blew up the Student Union Building - the historic centre of student resistance during the British period. Skirmishes between the military and students erupted over the next several years, with the most serious occurring in 1974. When the remains of U Thant, the third secretary-general of the United Nations, were returned to Burma, students and monks seized the coffin because the government did not intend to properly honour his remains. They took them to the university where, after a few days, the army used force, and killed more than a hundred students and monks in recovering the coffin (Selth 1989).

In 1987 the students, most of whom lived on the cash in their pockets, demonstrated against the demonitisation. A few months later, a minor fight between students and townfolk grew into large-scale student-army clashes and a major demonstration in Rangoon, which was suppressed by force, with forty-one students known to have died of suffocation in a police van; others were killed or jailed in the conflict.

The demonstrations of March did not end, despite the closing of the universities. When the universities were reopened in June, the students demanded an accounting of the missing and the arrest of those who inflicted injury upon them; this provoked new demonstrations. At the time, there were rice shortages and skyrocketing prices of basic goods in the cities; there also was large-scale unemployment. These and other issues finally brought the people onto the streets to join the student-led demonstrations. Martial law had been declared in several urban areas outside Rangoon. With the students at the head of the demonstrations and demanding real change in the political system - a return to democracy and constitutional government - the situation slipped out of the control of the military and threatened to bring down the nearly three-decade-old dictatorship (Lintner 1989). 


\section{On the Unity of the Army, 1948-1988}

It often has been noted that throughout the period of military rule the army remained united and intact. Ne Win could appoint and dismiss leaders with no fear of army resistance. He could call upon it to carry out the most brutal suppression of the people without fear that it would reject his command.

The officers in the Burma army have come from three sources: from the ranks; from students and graduates of the universities of Rangoon and Mandalay, who were given ROTC training and after entering the armed forces completed the Officers Training School (OTS) course. Under Ne Win, the first category were the most trusted, especially if they had served under him in his first postwar command, the 4th Burma Rifles. They formed a close camaraderie, and such men as Aung Gyi, Tin Pe, San Yu and Sein Lwin rose to leadership this way. The academy graduates were intended to be the army elite; they were carefully selected and given an education comparable to that offered at the universities. The ROTC produced engineers and doctors mainly; however, some, upon entering the armed forces, became line officers and they represent the best educated amongst the senior command. Enlisted men have been drawn almost exclusively from amongst the rural population. They have had less education generally than urban youth and the military has offered an opportunity to live better and earn more than if they remained peasants. They have proven to be very loyal soldiers who respond faithfully to command. The army has also recruited soldiers from amongst some of the minorities who were thought to be less political and most loyal to the national government. The Chins are believed to be the most numerous at the present time.

The persistent unity within the army can be traced to three sources: training, ideology, and its self-declared special position in society. As noted earlier, the initial Burman component of the army was trained by the Japanese and absorbed its traditions of absolute authority, brutalisation of the troops and officers who delayed or questioned orders, and centralisation of command. This was the glue that held the units together and punishment for individual initiative ensured that no deviation occurred.

The special position in society was a by-product of the army's central ideology. It saw itself as the most patriotic and loyal body in the nation. It had fought for independence and was in the front line of defence against both external and internal enemies. Because of its willingness to sacrifice everything for the people and the state, it saw itself as entitled to good housing, pay and benefits. During the democratic period, a two-class society emerged, with the army bases better built and cared for than the housing of the ordinary people. Through the Defence Services Institute the army expanded into the economic realm, where eventually, 
during the caretaker government, it organised and ran several large economic enterprises. From this period, the army argued that it not only defended the nation from its enemies but was the friend and helpmate of the farmer and worker, sharing in the harvesting and in building roads and dams. Throughout the period of the constitutional dictatorship this theme of friendship and partnership dominated in the press and at public events.

For all the apparent internal unity in the army, there was dissent in its officer ranks. In 1976, a coup against Ne Win was launched by more than a dozen junior officers. They were intent upon returning civilian leaders to power and the military to professional tasks. In court, the accused argued that they were dissatisfied with the political and economic system imposed on Burma by their leaders and with the corrupting influence of politics in the army. The failure of the coup and the conviction of the accused placed Academy graduates under suspicion, and many were diverted to administrative and party duties. Until 1988, military leadership remained in the hands of officers who rose from the ranks, from the OTS and from close association with Ne Win (Silverstein 1977); since then, Academy graduates have risen to leadership in SLORC, and General Maung Aye, a member of the first class at the Academy, is the second-highest ranking officer in the army.

\section{Military Rule: Third Phase, 1988-1993}

On the day before the 1988 coup, the minister of Defence ordered all members of the armed forces to resign from the BSPP and resume performing their 'original duties', working for the perpetuation of the state, for national unity and for the consolidation and strengthening of sovereignty. This was the first step towards ending party control, dismantling the constitutional dictatorship and reasserting the army's determination to rule directly. Immediately following their seizure of power, the coup leaders explained their action as halting the deteriorating conditions in the country and announced three immediate goals: (1) restoring law, order, peace and tranquility; (2) easing the people's food, clothing and shelter needs; and (3) holding democratic multi-party elections, once the first two goals were established. It also declared that all parties and organisations willing to accept and practise genuine democracy could make preparations and form parties. It abolished the state institutions and, in their place, created a State Law and Order Restoration Council (SLORC) comprising nineteen senior military officers under the leadership of General Saw Maung, the former minister of Defence and army chief of staff.

Also following the coup, the army dropped the original ethnic names of its military units. This was the last step in erasing its original federal structure.

Under martial law and arbitrary decrees, parties were able to form, but they were 
limited in their access to the media, and in their ability to hold rallies and communicate with their constituents. During the period of registration, 234 parties formed and all but one went onto the electoral rolls. Only a few were genuinely national, with leaders who attracted a wide following and offered some sort of program if they came to power.

The electoral law was highly restrictive and limited the ability of the parties to campaign and get their messages to potential supporters. Yet, despite the impediments to free and open campaigning established in the electoral law, the people took full advantage of the free election and voted overwhelmingly for the party which was recognised by all as being anti-military and pro-democracy. The National League for Democracy, led by Daw Aung San Suu Kyi and former General Tin U gained 392 of the 485 seats in the new People's Assembly, even though its leaders were either under house or direct arrest and the party was harassed in its efforts to reach its supporters.

Despite the coup leaders' promises to return power to the people and permit the People's Assembly to convene, the military had no real intention of doing that if the party and leaders it favoured did not win.

On 27 July 1990 they tore away their democratic mask and revealed their true authoritarian character. In their Announcement 1/90 they declared that SLORC was not bound by any constitution; it ruled by martial law and gained legitimacy from international recognition both by the United Nations and individual states. It declared that while it continued to rule, the elected members were responsible only for drafting 'a constitution for the future democratic state'. Nearly a month later, General Saw Maung said in a press conference that all previous constitutions ceased to be effective after the coup leaders seized power in 1988 (International Human Rights Law Group 1990:26-27).

While the elected members of the People's Assembly wait to assemble, SLORC continues its abuse of human rights by arbitrary arrest and imprisonment of the electees as well as citizens at large. Under Martial Law Order 1/89, military courts were established with power to severely punish, including issuing the death penalty for violators of SLORC decrees and pre-existing laws. In November 1989 Amnesty International reported that thousands of people had been arrested and convicted; other sources reported that more than 100 had received the death penalty (Amnesty International 1990a:1).

In the hill areas, the military pursues a dual policy to bring the civil wars to an end. Since 1989, it has offered individual ceasefire agreements that allow ethnic insurgents to retain their weapons and control local administration and economy in exchange for halting their wars against the state. All political issues remain unresolved until a new constitution and elected government are in place. For those 
who refuse the offer, war continues. By 1996, fourteen opposition groups had signed. Only the Karens have refused; the Karenni resumed warfare after the Burma army broke the agreement.

A key tactic of the military to force acceptance of an agreement is the persecution, torture, rape and murder of non-combatant old men, women and children of the minorities. By using innocent villagers as forced labour both in warfare and behind the lines, the army violates the human rights of civilians. These abuses are widely documented and reported by government agencies and non-governmental organisations.

Since 1989 the UN Commission on Human Rights in Geneva has pursued the issue of human rights violations in Burma. After listening to the reports of its special rapporteur and the testimony of representatives from various countries and nongovernmental organisations, beginning in 1991 and continuing through its 1996 sessions the Commission adopted strong resolutions. Initially the Commission acted under a rule of secrecy, but the failure of Burma's military rulers to give full cooperation to its special rapporteurs and to make appreciable progress in correcting identified abuses led the Commission, in 1993, to make public its proceedings and reports.

SLORC's rule in Burma has drawn the continuous attention of the UN General Assembly since 1992. Following discussions in its Third Committee, it unanimously adopted strong resolutions calling on Burma's military regime to release Daw Aung San Suu Kyi, the Nobel laureate, and other political prisoners, to halt human rights violations, and to restore democracy.

Faced with growing hostility from the world community, and in need of foreign aid, investment and technical assistance, on 23 April 1992 SLORC began a series of steps it hoped would indicate that political change was in progress and that the military's iron grip was relaxing. Change began at the top, with General Than Shwe, the minister of Defence and commander-in-chief of the armed forces, replacing General Saw Maung as leader of SLORC. At the same time, SLORC announced that political prisoners who no longer were a threat to the regime would begin to be released. It also announced that Daw Aung San Suu Kyi could receive visits from her immediate family, and that if she promised to end her involvement in national politics she was free to leave the country.

Earlier in the same year, Muslims of Indian origin living in Arakan, many of whom are citizens of Burma, harassed and under pressure from the Burma army, began fleeing the country and seeking refuge in Bangladesh. The outflow led to a border incident between the two states and the mobilisation of tens of thousands of troops on both sides of the border. But tensions began to relax following the change in SLORC leadership and on 28 April the two countries agreed to an orderly 
return of the refugees if they could prove their citizenship or right to be in Burma.

Also, about the same time, General Than Shwe announced a halt to the military campaigns against the Karen, although he did not declare a ceasefire or take steps to halt fighting against other minorities.

But the change that attracted most attention was SLORC's announcement that it would shortly begin a protracted process of writing a new constitution as the first step towards transfer of political power. On 23 June 1992 it convened a preconvention assembly of forty-three selected individuals, including candidates elected in 1990 to the parliament which they were never allowed to form, and fifteen representatives of the military. Their assignment was to decide who should be invited to the next stage of constitution-making, the drafting of principles and agreeing on chapter headings (Silverstein 1992).

To prepare for this second stage, SLORC promulgated Order 13/92 which set forth the six principles which the military rulers wanted the delegates to adopt as the basis of the new constitution: the unity of the territory, the people and the state; a multi-party democratic system; the incorporation of the principles of justice, liberty and equality, and 'the participation of the Tatmadaw [army] in the leading role of national politics of the State in future'.

With these and other instructions, the national convention of SLORC-selected delegates assembled in January 1993. From the start it did not go as planned. The military managers were forced to adjourn after two days when some of the delegates wanted to talk against the sixth principle and about other topics. The meeting reassembled but adjourned four times during the first six months of the year. By 1994 , the national convention had adopted more than 100 principles. On the future rule of the military in government, it agreed that one-quarter of the representatives in parliament would come from the military. They would be named by and responsible to the Commander-in-Chief; he would also name the ministers of defence, interior and border affairs, as well as have absolute power in times of emergency (New Light of Myanmar, 9 April 1994). The president must have long military experience. The armed forces budget would not be reviewed by the parliament.

More than four years have passed since SLORC announced its intention to oversee the writing of a new constitution. The people have yet to have a say. Their elected representatives were screened by SLORC, and when any of them refused to go along with the military representatives and spoke out they were disqualified; some left of their own accord, fearing that their outspokenness might land them in jail. On the basis of progress made thus far, General Tin U's prediction about the length of time that might pass before the SLORC gives way to some other ruling body may not be too far from the mark. And when the soldiers-in-power get 
the signatures of their hand-picked delegates on the document they are readying for them, and have the document ratified by the public, they will have the legal basis for a new constitutional dictatorship under which they can rule indefinitely.

\section{Conclusion}

The five-decade-long history of independent Burma is one of struggle both to establish a modern democratic political system and to unite the people under its rule. Thus far, it has failed on both counts. But the struggle has not been in vain. Military rule has convinced even the most sceptical that a true democracy is the only way domestic peace, freedom and personal safety can be restored. If democracy failed in its first trial, most people in Burma are more than ready to give it a second trial.

Military dictatorship and human rights violations have destroyed the myth of the unity between the soldiers and the people; today, the army is the most hated and feared organisation in the country. And while the military has fashioned a jail out of the once free country, the people, as demonstrated in the 1990 election, will do what they can to recover the freedom they thought they achieved when Burma became independent in 1948.

The minorities, too, have concluded that their future lies in a union with the Burmans and not outside. They are willing to lay down their weapons and join the Burmans in forming a viable federal state, based on equality, autonomy and self-determination. They want modernisation and development to come to their areas and people, but on terms they can accept and live with.

Six years ago a handful of elected representatives fled to Manerplaw, the Karen headquarters on the Burma-Thai border, and with the backing of the Democratic Alliance of Burma - a political front of minority and Burman groups - established the National Coalition Government of the Union of Burma (NCGUB) as a rival to SLORC. The leader, Dr Sien Win, is the cousin of Daw Aung San Suu Kyi. Although it has not received formal international recognition, its members travel widely and speak often to parliaments, political leaders and the press; they have a headquarters in the US and lobby at the UN, keeping the issue of Burma before them. Both the Burmans and the minorities want to see the military return to the barracks, leaving politics to civilian elected representatives. Until democracy is re-established, there will be disunity, warfare and economic decline in Burma. 